Article

\title{
Linking Financial Resources Ability and R \& D Resources on New Product Performance. The Mediating role of Innovation Orientation and Competitive Position
}

\author{
Hersugondo ${ }^{1}$, Sugeng Wahyudi ${ }^{2}$, Nuryakin ${ }^{3 *}$ and Rio Dhani Laksana ${ }^{4}$ \\ 1 Faculty of Economics and Business, Universitas Diponegoro Semarang, Indonesia; gondosakti@yahoo.com \\ 2 Faculty of Economics and Business, Universitas Diponegoro Semarang, Indonesia; sug w@yahoo.com \\ 3 Master of Management Department. Postgraduate Program. Universitas Muhammadiyah Yogyakarta. In- \\ donesia; nuryakin@umy.ac.id \\ 4 Faculty of Economics and Business, Universitas Jenderal Soedirman, Purwokerto, Indonesia ; riodhani@un- \\ soed.ac.id \\ * Correspondence: nuryakin@umy.ac.id
}

\begin{abstract}
This study aims to test empirical research on the effect of financial resource ability, research and development ( $\&$ \& ) on innovation orientation and competitive position. This study also examines the critical mediating role of innovation orientation and competitive position to achieving new products performance (NPP). This study used a quantitative research approach by comparing data from service industry and manufacture industry in Indonesia included in Indonesian-State-Ownership companies. The analysis unit in this study used middle managers and top managers who responsible for managing divisions within the Indonesian-State-Ownership companies. The number of respondents studied in this study was 287 sample. The purposive sampling technique was used in taking the research sample. This study indicated that financial resources abilities, research and development ( $R \& D$ ) abilities positive effect on innovation orientation and competitive position. This study also testing the importance role of innovation orientation and a competitive position to enhancing new products performance (NPP).
\end{abstract}

Keywords: financial resources ability, $R \mathcal{E} D$, innovation orientation, competitive position, new product performance (NPP)

\section{Introduction}

New Product Performance (NPP) still attracts many researchers and company managers to discuss, especially in measuring its degree of success and long-term growth [1]. Guimaraes and Paranjape [2] explain that companies' success in developing new products is essential in facing the increasing intensity of business competition. The successful long-term business through new product development is also considered a determinant of a company's long-term excellence through innovation creation [3]. Moreover, changes and increasingly fast business dynamics also require companies to adapt quickly through active responses to customer complaints [4], building business networks [5], innovation-oriented [6], and company investment in R\&D activities [7].

These changes and business dynamics force managers to recognize the company's importance in creating new successful products through continuous R\&D activities to measure new product performance success. This strategy is essential for managers because it contributes to achieving the company's strategic and long-term goals. Several literature reviews that discuss companies' importance in achieving successful new product performance have conducted in-depth studies [3, 8-11].

Globalization and the development of technology and information have also had consequences for companies in creating new products [12]. Companies must defend their market amid increasingly fierce competition and even need to seize the market from existing competitors. One of the companies' efforts to gain market share includes innovating, 
financial resources, and its ability to conduct $R \& D$ [13-16]. Other researchers found that company capability was the key to an organization achieving competitive advantage by creating low-cost advantages and differentiation advantages to be better known than competitors' products [17].

Companies also need to allocate their internal resources as a competitive advantage source [18]. Internal capability as a competitive advantage source will create distinctiveness for the company compared to its competitors and directly guarantee superior company performance. One of the company's internal capabilities in achieving a competitive advantage is its financial resources, which can guarantee its operations in achieving its long-term goals [6, $19,20]$.

Several previous studies have explained that the process of creating new products was considered insignificant for the company. Still, in the current market competition era, creating new products is a critical part of the company [21]. Garud, Jain [22] explain that innovation and new product development techniques do not change rapidly for companies in a stable market environment. Meanwhile, the current condition where the product life cycle is experiencing rapid development requires companies to innovate [23]. Innovative products are essential in the industry. By creating innovative products, consumers can benefit from both the new features, design, and functionality of a product [24]. The competitive era is no longer offering similar products or competing for several reasons, such as selling price and quality. Some companies consider that the trend is inevitable, so companies need to differentiate product offerings from innovation to gain a competitive advantage over competitors by creating value for customers [25].

Dabla-Norris, Kersting [26] reveal that today's industries are characterized by gradually or rapidly-produce changes, new trends, and developments requiring a quick response from companies to focus on innovation and company productivity. The drivers of business change are not limited to changes in the short-term industrial growth rate, but on the advantages of position, how the company uses its financial capabilities, changes in technology and innovation processes, and improvements in new product performance [27]. Innovation makes an important contribution to sustainable growth [28] and developmental model for the innovative capacity and performance [29].

Furthermore, this study has two specific objectives: first, to test the effect of financial resource ability, research, and development resources on the innovation orientation and competitive position empirically. The second is to test the critical mediating role of the innovation orientation and competitive position in improving new products' performance. This study aims to build and test basic theoretical models and build empirical research models for later hypothesis testing. Hypothesis testing used a quantitative research approach with structural equation modeling (SEM) with a sample of 287 lower, middle, and upper managers of Indonesian Indonesian-State-Ownership. Besides, this study contributes to the body of knowledge in the study of Resource-Based Theory in achieving positioning advantages and companies' long-term performance [30]. This study was conducted by taking samples at the managerial level of stateownership companies. This study observed the condition of Indonesian-State-Ownership company after the policy issue regarding the merger of businesses and holding companies became an exciting issue amid the global crisis that hit several developed countries. Therefore, this study's results will provide practical implications regarding the strategic role of innovation and superior position for Indonesian-State-Ownership company in Indonesia. 


\section{Theoretical Framework}

\subsection{Resources Based View}

Resource-Based View (RBV) is often used to understand strategic marketing problems, but it cannot be adopted within the organization's scope. The concept of company resources in the research developed by [30] explains the intangible resource factors determining its success. These factors consist of capacity, talent, competence, skill, and core competence.

Resource-Based Theory was initially pursued by [31]. In his view, [31] states that companies have resources to make the company have a competitive advantage and direct the company to have good long-term performance. Valuable and scarce resources can be directed to create competitive advantage so that the resources can last a long time and are not easily copied, transferred, or replaced. Resource-based companies will continue to maintain their competitive advantage by utilizing existing capabilities. Competitive advantage, according to Wernerfelt [32] $]_{\llcorner}$is part of the Resource Based-View theory, which emphasizes the heterogeneity of resources and the company's unique capabilities as a collection of strategic and productive resources for the company so that this can be used as a company's defense strategy to compete in the market. This approach will enhance the company's distinctive capabilities.

Resources are all tangible and intangible assets owned by the company. Barney [33] states that companies oriented towards business strategy are more directed at a unique differentiated advantage to generate marketing performance and a foundation for sustainable competitive advantage. According to Barney, competitive advantage is based on the Resource-Based View, namely providing superior value to consumers and making it difficult for competitors to substitute products to benefit the company apart from the scarcity and resource values attached to the company organization. Unique values will be the company's unique competence. A study conducted by Shih and Yang [34] found that the company's capabilities and intangible resources were company assets in achieving company growth towards a broader market.

\subsection{Competitive Position}

In the Resource-Based View (RBV), capabilities determine the roots of a company's sustainable competitive advantage. These capabilities can give birth to patents protected by law, technological knowledge, and valuable production skills that are difficult for competitors to imitate [35]. Newbert [36] states that the constructs of competitive advantage and performance are used interchangeably in different concepts, where competitive advantage is the implementation of strategies that facilitate cost reduction, exploitation of opportunities. Competitive advantage is a resource-based theory when companies exploit a combination of resource capabilities effectively so that competitive advantage refers to economic value to neutralize competitive challenges. Meanwhile, Singh, Misra [37] explain that performance can be measured from the growth of Return on Assets (ROA).

Although the resource-based view is considered underlying competitive advantage and performance, according to Hunt and Morgan [38], it is used to solve corporate diversity. Resource-Advantage Theory is an evolution from Barney's (1991) that changes intangibles to tangibles. This theory views resources as tangible and intangible entities that produce valuable companies' efficiency to segment the market. This theory views the company as a heterogeneous combination and as an imperfect resource. This theory completes the theory related to intangible resources. Barney (1991) describes heterogeneous marketing demand theory as an illustration of competitive advantage theory, describes intra-industrial demand in different market segments and the same industry, describes economic evolution with product innovation as a reference for economic growth, as consumer interactions, code traditions, and structures, political, economic, and social. 


\section{Hypotheses Development}

\subsection{The effects of financial resources ability on innovation orientation and competitive position}

According to Morgan [39] $]_{L}$ a company's performance success is determined by its internal capabilities and existing resources. The company's internal capabilities are closely related to dynamic capabilities, cross-functional coordination, architectural capabilities, and specialization. Chew, Yan [40] describe capabilities and strategies as the company's primary keys in achieving competitive advantage. Furthermore, there is a positive relationship between capabilities and strategic excellence. Company capability is also an essential asset in achieving a degree of strategic excellence and is the company's main driving factor in achieving superior performance.

Meanwhile, Dabla-Norris, Kersting [26], in their study, examined company-specific actions, especially innovation, in influencing company productivity and the role of finance in achieving firm productivity. The results of the study found that innovation was critical for company performance and can directly increase productivity. This study also found that the company's financial aspects also influenced the relationship between innovation and productivity. Khin, Ahmad [24] reinforced previous studies' results, explaining the importance of innovation in corporate strategy and resources. In the strategic approach, innovation was considered something that differentiates the company from its competitors [41]. Lynn and Akgun [42] agree with a previous study that found that companies' innovation strategy was essential. Innovation could be divided into three forms: customer-driven strategy, processdriven strategy, and pioneer driven strategy. In another study, Lynn, Mazzuca [43] argued that innovation could be distinguished by, among others, process-based, strategy-based, speed-based, market-based, learning, and qualitative innovation.

Thus, based on the theoretical review and previous research provided, the researchers proposed hypotheses to investigate the effects of financial resources ability on innovation and competitive position:

H1: Financial resources ability has a significant positive effect on innovation orientation

H2: Financial resources ability has a significant positive effect on the competitive position

\subsection{The effects of $R \& D$ resources on innovation orientation and competitive position}

$\mathrm{R} \& \mathrm{D}$ is a complex challenge for companies in expanding through the company's capacity to be creative and innovative [44]. The company is under considerable alienating pressure and competes with competitors. This alienation is due to the increased adaptation process and speed resulting from globalization and innovation [45]. Companies need to increase awareness of the value of customer knowledge in organizational processes and systems to cope with globalization pressures. The study of Bertrand and Mol [46] analyzed differences in antecedents and performance reports on R\&D. The results of the study found that the absorption capacity of R\&D may lead to more positive innovation outcomes, particularly product innovation. Meanwhile, Karbowski [47] explained that the R\&D process led to the emergence of product innovation compared to R\&D competition. Companies that maximize profits from competitive strategies in $R \& D$ because companies prefer to pursue $R \& D$ cartelization or industrial cartelization strategies, depending on on-demand elasticity about the company's investment in R\&D.

Innovation can be seen as an essential component of competitive advantage embedded in the organizational structure, production process activities, products launched, and marketing strategies within a company [48]. Furthermore, the basic guidelines for determining innovation activities at the company level are divided into four types of innovation: product innovation, process innovation, marketing innovation, and organizational innovation. This type of innovation, as a whole, has a positive impact on company performance.

Thus, based on the following theoretical review and previous research provided, the researchers proposed hypotheses to investigate the effects of $R \& D$ resources on innovation orientation and competitive position:

H3: R\&D resources have a significant positive effect on innovation orientation

H4: $R \& D$ resources have a significant positive effect on the competitive position 


\subsection{The effects of innovation orientation on new product performance}

Innovation provides support for corporate strategy choice in achieving organizational performance [49]. It is an essential function in management because innovation is related to company performance. A study conducted by Eshlaghy and Maatofi [50] emphasized the importance of innovation in achieving company performance. Meanwhile, in their study, Lin and Peng [51] found that entrepreneurial orientation affected innovation; orientation affected innovation; innovation also influenced business performance. New product development is an important innovation that must be done to fulfill new consumer trends [52]. The same results in Najib and Kiminami [53] proved that cooperation provided a significant relationship in creating innovation and encouraging performance. Besides, performance is a function of the achievements of the company's innovation activities. The results of these studies also indicate that innovation significantly affects business performance. Research on the effect of innovation by companies on performance was also conducted by Eris and Ozmen $[54]_{\iota}$ who found an influence of market orientation, organizational learning, and innovation on company performance.

With high technological turbulence levels, company experience is significantly related to innovation and company growth [55]. In an environment of low technological turbulence, the relationship between innovation and company growth does not exist. The study contributes to the entrepreneurship literature by showing that the experience can promote innovation and firm performance in a highly volatile environment. Meanwhile, a study conducted by Nuryakin [56] also found that innovation was an essential key in achieving performance.

Thus, based on the following theoretical review and previous research provided, the researchers proposed a hypothesis to investigate the effects of innovation orientation on new product performance:

H5: Innovation orientation has a significant positive effect on new product performance.

\subsection{The effects of competitive position on new product performance}

Research by Nandakumar, Ghobadian [57] found environmental dynamics and competition as moderating effects in the relationship between business strategy and competitive performance levels. In a low, competitive environment of leadership strategies and a highly competitive environment, performance differentiation strategies are better than competitors. In a highly dynamic environment, leadership strategy, and dynamic environment, differentiation strategy helps enhance performance. A study with similar results was conducted by Chew, Yan [58] also summarized SMEs' core capabilities and competitive strategies and impacted improving performance.

Other studies found that it was important for companies to be critical of their innovation, which was an integral part of the company and an opportunity for its future success [59]. The results of other studies also found that many companies innovated, both in the form of technological and marketing innovations [60,61]. Meanwhile, Taylor [62] found that product development through new technology showing internal competition affected product technology development. There are two ways to use technology in product development. First, new technologies can allocate resources to gain a deeper understanding of the innovation process. Second, access to internal information and mobility across boundaries is beneficial in utilizing company-owned technology.

Thus, based on the following theoretical review and previous research provided, the researchers proposed a hypothesis to investigate the effects of competitive position on new product performance:

H6: Competitive position has a significant positive effect on new product performance 


\section{Research Methodology}

This study used a quantitative research design and attempted to examine the correlational relationship between exogenous and endogenous constructs. The quantitative design was to test the research hypothesis. Meanwhile, this study's sample was the managerial level of Indonesian-state-ownership (BUMN) companies in several Indonesian regions, such as West Java, Jakarta, East Java, Central Java, and DIY. The companies sampled in the study included the service industry, trade, retail, manufacturing, insurance, and banking. Primary data was used in the research collected using surveys through online and offline questionnaires conducted on respondents of the managerial level of BUMN in Indonesia.

\subsection{Data Screening and Trimming}

Data screening and trimming in the study were conducted before further in-depth analysis to ensure the data's feasibility. Data screening was done by testing each respondent's answers' consistency by looking at the extreme standard deviation. Meanwhile, data trimming was carried out by looking at the consistency of the open and close answers filled in by respondents. The data screening and trimming results were conducted on 287 samples, with 59 respondents online and 155 respondents offline. The random sampling approach was used in the sampling technique. The questionnaires were distributed over three months.

\subsection{Demographic Analysis of Research Samples and Measurement of Variables}

The data collection process was carried out through a survey at the managerial level of BUMN in Indonesia. This study examines the relationship between financial resource construction, R\&D resources, innovation orientation, competitive position, and new product performance. The researchers then tested each construct's instruments, financial resource ability, research and development resources, innovation orientation, competitive position, and new product performance. The researchers also conducted a pilot test to test the content analysis and reliability validity of 287 managers. Several questionnaires need to be corrected by adopting the previous studies.

\subsubsection{Respondent Characteristics}

The testing respondents' characteristics are divided into several characteristics, including gender, age, position, level of education, and managers' experience. There were 164 male respondents or $87.2 \%$ and 24 female respondents or $12.8 \%$ based on these characteristics. 76 respondents or $40.4 \%$ were $>45$ years old; 46 respondents or $24.5 \%$ were 31 - 35 years old; 32 respondents or $17 \%$ were 41 - 45 years old; 26 respondents or $13.8 \%$ were 36 - 40 old; and 8 respondents or $4.3 \%$ were 26 - 30 years old.

Eighty-five (85) respondents or $45.2 \%$ were in lower manager position as the next characteristic; 58 respondents or $30.9 \%$ were in middle manager position; 45 respondents or $23.9 \%$ were in a top manager position.

Ninety-seven (97) respondents or $51.6 \%$ had a master's degree in the education level; 70 respondents or $37.2 \%$ had a bachelor's degree; 9 respondents or $4.8 \%$ had a Ph.D. degree; 5 respondents or $4.3 \%$ graduated from junior high school; 4 respondents or $2.1 \%$ came from secondary school.

Eighty-six (86) respondents or $45.7 \%$ have worked in a managerial position for 11-20 years as the work experience experiences; $21-30$ years as 63 respondents or 33.5\% have worked for 21-30 years; 38 respondents or 20.7\% have worked for 1-10 years in the same position.

\subsubsection{Business Scope Characteristics}

The business scope's characteristics can be categorized into four parts: operational scale, business scope, market conditions, and potential business. The business characteristics based on the manufacturing scale had a total of 126 companies or $67 \%$, medium-scale operations of 52 companies or $27.7 \%$, small scale operations of 10 compa- 
nies or $5.3 \%$, business coverage of service companies of 132 companies or $70.2 \%$, fast-moving operation products of 7 companies or $3.7 \%$, industrial products of 11 companies or $5.9 \%$ and durable products of 38 companies or $20.2 \%$.

\subsubsection{Market Conditions}

Market conditions' characteristics can be categorized into four parts: perfect condition, monopolistic competition, oligopoly, and monopoly. Perfect conditions had 71 respondents or $37.8 \%$. The monopolistic competition had 49 respondents or $26.1 \%$. Monopoly had 68 respondents or $36.2 \%$, while oligopoly did not exist $(0 \%)$.

\subsubsection{Business positioning}

Business positioning characteristics can be categorized into four parts: market leaders, market challengers, market followers, and market nicher. The market leader business had 114 respondents or $60.6 \%$; the market challenger had 13 respondents or 6.9\%; the market followers had 39 respondents or $39 \%$; the nicher market had 22 respondents or $11.7 \%$.

\section{Validity and Reliability Measurement}

The instrument's validity and reliability tests were carried out using Confirmatory Factor Analysis (CFA) by looking at each construct's loading factor value with its indicators. The validity test results show that each instrument's value has a loading factor value of $>0.6$. Thus, it is statistically valid. The results are explained in Table 1 below.

Table 3. Scale item for measures

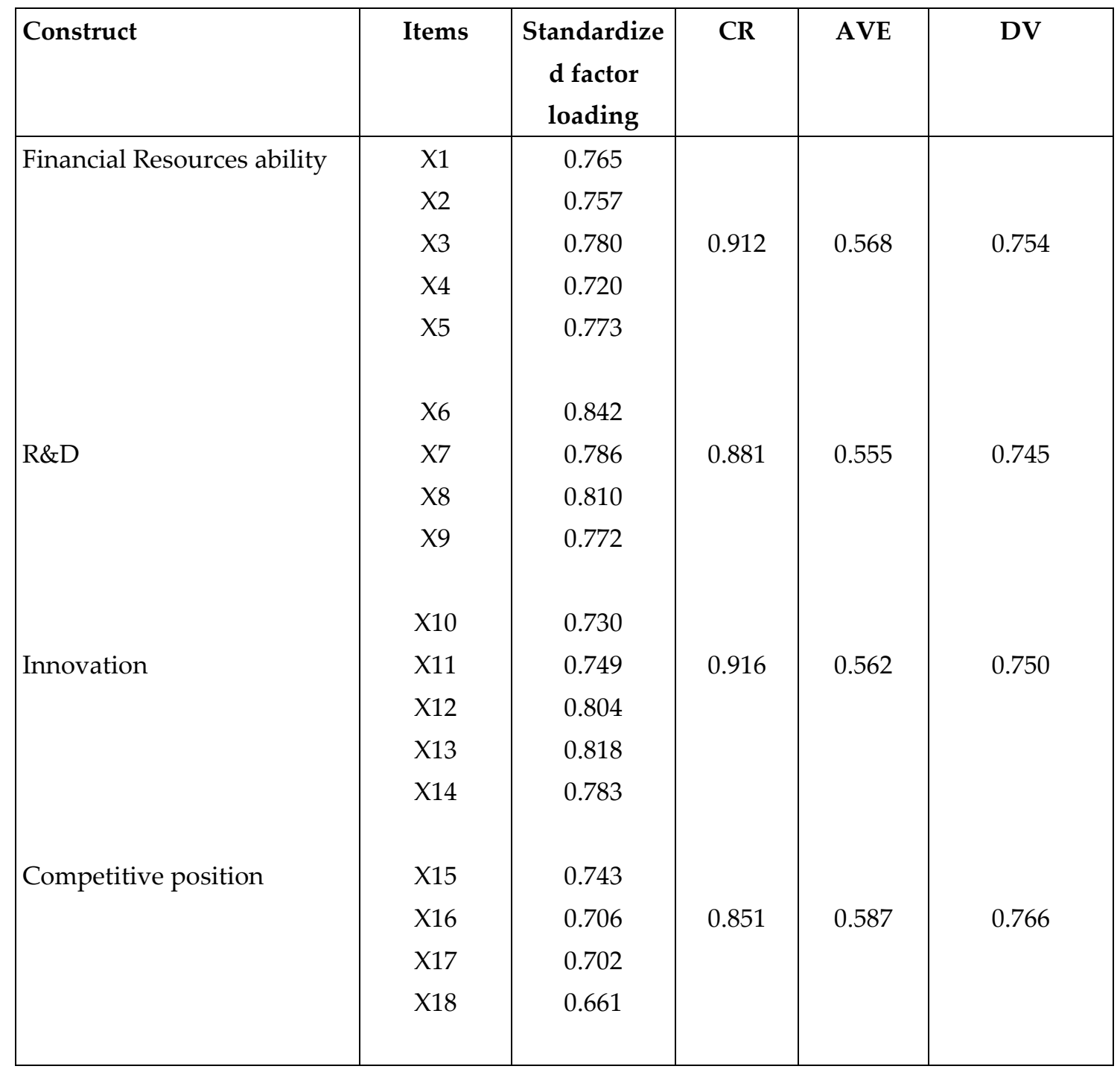




\begin{tabular}{|l|c|c|c|c|c|}
\hline New Product Performance & X19 & 0.786 & & \\
& X20 & 0.760 & 0.912 & 0.568 & 0.754 \\
& X21 & 0.696 & & \\
& X22 & 0.792 & & \\
& X23 & 0.762 & & \\
\hline
\end{tabular}

\section{Result of the Study}

This study used Structural Equation Modeling (SEM) approach to analyze the research aim and hypotheses testing with AMOS software. Structural Equation Modeling examined the two categories of data analysis, the measurement research model and the structure research model. The result of this study is shown here below. Figure 2 shows the results of the structural model testing in this study. Overall, the measurement of model fit in the structural equation modeling indicates that the value of the fit model is quite good, namely $(\mathrm{GFI}=0.889, \mathrm{AGFI}=0.863, \mathrm{RMSEA}=$ $0.019, \mathrm{CFI}=0.922$, TLI $=0.911$ ). The full model test results show good results shown in the goodness of fit criterion. In testing the model's structure, it describes models of causality in research with tiered relationships. The test results show several other goodnesses of fit criteria that fulfill, such as the Chi-Square of 237,730. The probability value is 0.238 . This result indicates that the research model is accepted and meets the specified criteria (standards).

Overall, the estimated paths test show that all hypotheses have significant support in hypothesis testing. There are six hypotheses built in this study. The full model test results in this study are shown in Figure 4 . The test results of each hypothesis are explained in the following figure.

\section{Figure 3. Hypothesis Testing Model}

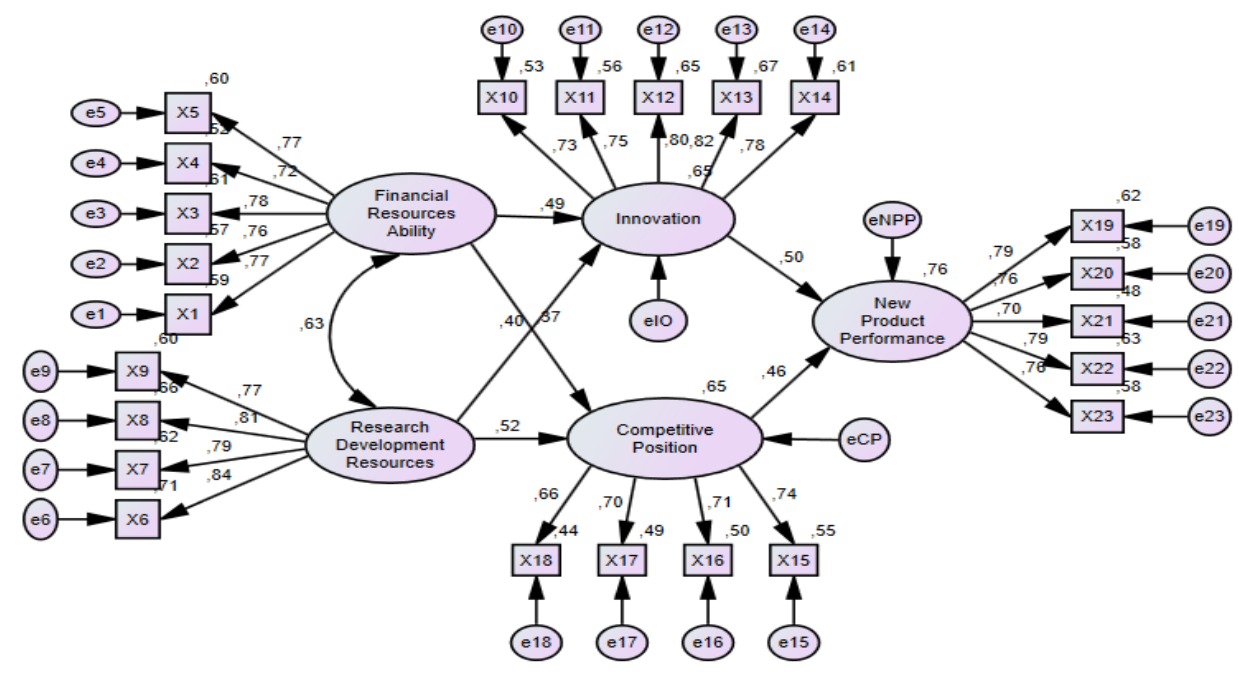

Chi-square $=237,730 ;$ Probability $=, 238 ; \mathrm{DF}=223 ; \mathrm{CMIN} / \mathrm{DF}=1,066 ; \mathrm{GFI}=, 889 ; \mathrm{AGFI}=, 863 ; \mathrm{CFI}=, 922 ; \mathrm{TLI}=, 911 ; \mathrm{RMSEA}=, 019$

In this study, hypothesis testing was carried out through statistical testing with the path analysis approach in testing mediation regression in Table 5. The results of testing on hypotheses 1 to hypothesis 6 are explained as follows. 
Table 2.Test Results for Mediating Regression for financial resources ability, R\&D resources, innovation orientation, competitive position, new product performance

\begin{tabular}{|c|c|c|c|c|c|}
\hline Hypothesis & & $\begin{array}{c}\text { Standardized } \\
\text { path } \\
\text { coefficients }\end{array}$ & $\begin{array}{c}\mathrm{t} \\
\text { value }\end{array}$ & Prob. & Result \\
\hline $\mathrm{H} 1$ & $\begin{array}{l}\text { Financial resources ability } \rightarrow \\
\text { innovation }\end{array}$ & 0.451 & 4.992 & 0.000 & Significant \\
\hline $\mathrm{H} 2$ & $\begin{array}{l}\text { Financial resources ability } \rightarrow \\
\text { competitive position }\end{array}$ & 0.345 & 3.631 & 0.000 & Significant \\
\hline $\mathrm{H} 3$ & $R \& D \rightarrow$ innovation & 0.381 & 4.287 & 0.000 & Significant \\
\hline $\mathrm{H} 4$ & R\&D $\rightarrow$ competitive position & 0.493 & 4.876 & 0.000 & Significant \\
\hline H5 & $\begin{array}{l}\text { innovation } \rightarrow \text { new product } \\
\text { performance }\end{array}$ & 0.617 & 4.799 & 0.000 & Significant \\
\hline H6 & $\begin{array}{l}\mathrm{R} \& \mathrm{D} \rightarrow \text { new } \\
\text { performance }\end{array}$ & 0.565 & 4.495 & 0.000 & Significant \\
\hline
\end{tabular}

Notes: ${ }^{*} p, 0.10,{ }^{* *} p, 0.05$ and ${ }^{* * *} p, 0.01$; the standardized coefficients are reported with the $t$-values in parentheses

The hypothesis testing results in Table 2 show the value of the standardized path coefficients of financial resources ability, research and development resources, innovation, and competitive position on new products' performance. The six hypotheses built in this study are the influence of financial resource ability, R\&D resources, innovation, and competitive position on new products' performance. The results of testing each hypothesis are as follows.

- The h1 statistical test results obtain a path coefficient value of 4,992 and a significance value of 0,000, indicating that financial resources ability has a significant positive effect on the innovation orientation.

- The h2 statistical test results obtain a path coefficient value of 3,631 and a significance value of 0,000, indicating that financial resources ability has a significant positive effect on competitive position.

- The h3 statistical test results obtain a path coefficient value of 4,287 and a significant value of 0,000 , indicating that R\&D has a significant positive effect on the innovation orientation.

- The h4 statistical test results obtain the path coefficient value of 4.876 and a significance value of 0.000 , indicating that $R \& D$ has a significant positive effect on a competitive position.

- The h5 statistical test results obtain a path coefficient value of 4,799 and a significance value of 0,000, indicating that the innovation orientation has a significant positive effect on the innovation of new product performance.

- The h6 statistical test results obtain the path coefficient value of 4.495 and a significance value of 0.000 , indicating that competitive position has a significant positive effect on new product performance.

\section{Discussion and Conclusion}

The test results on the first hypothesis indicated that financial resources ability had a significant positive effect on innovation orientation. The results of this study support the previous study conducted by Khin, Ahmad [24] $]_{L}$ who found the importance of companies to strengthen innovation in corporate strategy and resources. Lynn and Akgun [42] also support this study's results, finding that companies' innovation strategies were necessary. Dabla-Norris, Kersting [26], in their study, also explained company-specific actions through innovation in influencing company productivity and the role of financial capacity in achieving company productivity. These studies also support the findings of testing the second hypothesis, showing that financial resources ability had a significant positive effect on competitive position.

The third hypothesis's test results indicated that $R$ \& D had a significant positive effect on innovation orientation. This study's results are in line with previous research. The additional process of adaptation and speed resulted from 
globalization and innovation, so that companies should increase awareness of the value of knowledge about customers [45]. The study's findings by Bertrand and Mol [46] also support this research on antecedents and performance consequences on R\&D. Karbowski $[47]_{\llcorner}$in his study, also explained that companies needed to maximize the advantages of competitive strategies in R\&D. Innovation are also an important marketing strategy for companies to achieve excellence [48]. These studies also support the findings of testing the fourth hypothesis, showing that R\&D had a significant positive effect on competitive position.

The fifth hypothesis's test results indicated that the innovation orientation had a significant positive effect on the innovative new product performance. This study's results align with Najib and Kiminami [53] $]_{\llcorner}$who proved innovation creation could drive performance. In their study, Eris and Ozmen [54] also found the effect of innovation on company performance. The company experience was significantly related to innovation and growth [55]. This study also supports the previous study conducted by Nuryakin [56], with the findings of innovation being an essential key in achieving performance.

The sixth hypothesis's test results indicated that competitive position significantly affected new product performance. The results of this study support the previous study conducted by Nandakumar, Ghobadian [57], proving that environmental dynamics and competition had a relationship at the level of competitive performance. This study is also in line with Chew, Yan [58]. They found that competitive strategies affected performance improvement. Other studies aligned with this study show how innovation is an essential part of the company and an opportunity for its future success [59].

\section{Research Implications}

The study results proved the critical mediating role of the innovation orientation and the competitive position in improving the performance of new products empirically. Besides, this study's results attempted to answer the research objectives, which contributed empirically to the influence of financial resources ability, research and development resources, innovation orientation, competitive position, and new product performance. This study also contributes to the body of knowledge in resource-based theory studies (resources-based view) in achieving corporate positioning and long-term performance excellence (Barney, 1991). This study empirically proved the effect of financial resurrection ability, $R \& D$ resources, innovation orientation, competitive position, and new product performance in previous studies conducted by several previous researchers, which still provided contradictory results.

This study's results provided practical implications for the research sample, namely the managerial level of BUMN in Indonesia, related to corporate strengthening strategies through financial resource capacity, R\&D resources, innovation orientation, competitive position, and new product performance. Strategies developed by BUMN managerial levels include the following:

- Financial resurrection ability can be strengthened through the availability and access to adequate financial resources, including cash flow and the ability to provide capital to support company innovation.

- $\quad R \& D$ resources are strengthened by a strategy to increase the intensity of R\&D activities, R\&D investment, new product development activities, and new product launches.

- Based on research results, innovation orientation can be carried out, actively seeking innovation and innovation ideas accepted by company management.

- Competitive Position can create products or services that are difficult to imitate by competitors, creating distinctive products according to customer demands and tastes, streamlining production/service costs, and focusing on consumer demand.

- Performance of new products can be done with a focus on customers and market demand, the introduction of new products/services, use of information technology, adaptation processes to market conditions, creating unique products compared to competitors. 


\section{Future Research}

This study has several limitations. First, the sample used in this study was 287 managerial levels, taken from 4 locations of BUMN in Indonesia, namely West Java, Jakarta, East Java, Central Java, and DIY. The area is a large part of where the existence of the BUMN company is mostly located. The sampling technique used random sampling not to reflect the proportion of each type of BUMN in Indonesia. The sample collection does not always represent the finding's general population. A more diverse random sample based on the types and categories of SOEs is suggested in future research. To generalize this study's findings. Second, this study intended to test the determinants of new product performance from 4 constructs: financial resource ability, R \& D resources, innovation orientation, and competitive position. Whereas in previous studies, new products' performance was also determined by other than the four constructs. Thus, future research can explore other factors regarding business networks, information technology, and marketing capabilities. Third, studies discussing innovation orientation in influencing new product performance are still limited. Therefore, future research may explore more in-depth about the performance of new products.

\section{Aknowledgements}

The authors sincerely thank you to the LPPM (Lembaga Penelitian dan Pengabdian Masyarakat) Universitas Diponegoro for endorsing the grand research project on High Reputation of International Publication Grand, and all the respondents who participated in finishing the survey for Indonesian State-Owned -Enterprises manager.

\section{Reference}

1. Cheng, C.C.J. and D. Krumwiede, Enhancing the performance of supplier involvement in new product development: the enabling roles of social media and firm capabilities. Supply Chain Management: An International Journal, 2018. 23(3): p. $171-187$.

2. Guimaraes, T. and K. Paranjape, Competition intensity as moderator for NPD success. International Journal of Innovation Science, 2019. 11(4): p. 618-647.

3. Vinayak, K. and R. Kodali, The relationship between NPD innovation and NPD performance: the moderating role of NPD best practices in Indian manufacturing industry. Measuring Business Excellence, 2014. 18(2): p. 39-59.

4. Jayachandran, S., K. Hewett, and P. Kaufman, Customer Response Capability in a Sense-and-Respond Era: The Role of Customer Knowledge Process. Academy of Marketing Science. Journal, 2004. Vol. 32, 3: p. pg. 219.

5. Chen, Y.K. and N.C.a.C. Ranaweera, How does dynamic network capability operate? A moderated mediation analysis with NPD speed and firm age. Journal of Business \& Industrial Marketing, 2020.

6. An, W., Y. Xu, and J. Zhang, Resource constraints, innovation capability and corporate financial fraud in entrepreneurial firms. Chinese Management Studies, 2018. 12(1): p. 2-18.

7. Mairesse, J., P. Mohnen, and E. Kremp, The Importance of RED and Innovation for Productivity: A Reexamination in Light of the French Innovation Survey Annales d'Économie et de Statistique 2005. 79(80): p. pp. 487-527

8. Munck, J.C., et al., The performance effects of management control instruments in different stages of new product development. Journal of Accounting \& Organizational Change, 2020. 16(2): p. 259-284.

9. Luiz, O.R., et al., Impact of critical chain project management and product portfolio management on new product development performance. Journal of Business \& Industrial Marketing, 2019. 34(8): p. 1692-1705.

10. Martynov, A., Alliance portfolios and firm performance: the moderating role of firms' strategic positioning. Journal of Strategy and Management, 2017. 10(2): p. 206-226.

11. Tih, S., et al., Prototyping, customer involvement, and speed of information dissemination in new product success. Journal of Business \& Industrial Marketing, 2016. 
12. Bicen, P. and S.D. Hunt, Alliance market orientation, new product development, and resource advantage theory. Journal of Business \& Industrial Marketing, 2012. 27(7): p. 592-600.

13. Bednar, P. and M. Halaskova, Innovation performance and RED expenditures in Western European regions: Divergence or convergence? . Journal of International Studies, 2018. Vol. 11(1): p. pp. 210-224.

14. Chun, H., Determinants of RED cooperation in small and medium-sized enterprises. Small Bus Econ (2012) 39:, 2011. vol. 39: p. 419-436.

15. Matsuno, A.A.a.K., Mediating roles of capabilities between RED-marketing integration and business performance Journal of Asia Business Studies 2018. Vol 12(1): p. pp.81-98.

16. Suh, Y. and M.S. Kim, Effects of SME collaboration on RED in the service sector in open innovation. Innovation: Management, policy \& practice, 2012. vol 14: p. pp. 349-362.

17. Tan, Q. and C.M.P. Sousa, Leveraging marketing capabilities into competitive advantage and export performance. International Marketing Review, 2015. 32(1): p. 78-102.

18. Barney, J., Firm Resources and Sustained Competitive Advantage. Journal of Management, 1991. Vol. 17, 1;: p. pg. 99.

19. Oyewole, O.B., Empirical Analysis of The Effect of Financial Policy Reforms On Innovations In Nigeria's Banking Sector Savings and Development 1993. 17(2): p. pp. 153 - 169.

20. Zhang, L., Y. Zhang, and Z. Dong, The effects of financial sector opening on financial constraints in China, ed. T.C.E. Transformation. 2018.

21. Abecassis-Moedas, C., Integrating design and retail in the clothing value chain: an empirical study of the organisation of design. international Journal of Operations \& Production Management, 2006. 26(4): p. 412-428. Garud, R., S. Jain, and P. Tuertscher, Incomplete by design and designing for incompleteness. Organization Studies, 2008. 29(3): p. 351-371.

23. Loucanova, E., et al., Stakeholders' perceptions of the innovation trends in the Slovak forestry and forest-based sectors. Journal of Business Economics and Management, 2020. 21(6): p. 1610-1627.

24. Khin, S., N.H. Ahmad, and T. Ramayah, Product innovation among ICT technopreneurs in Malaysia. Business Strategy Series, 2010. 11(6): p. 397-406.

25. Nuryakin, N., V. Didiek Aryanto, and M. Budi, Mediating effect of value creation in the relationship between relational capabilities on business performance. Contaduría y Administración, 2017. 63(1): p. 1-21.

26. Dabla-Norris, E., E.K. Kersting, and G. Verdier, Firm Productivity, Innovation, and Financial Development. Southern Economic Journal, 2012. 79(2): p. 422-449.

Zhou, K.Z., Innovation, imitation, and new product performance The case of China. Industrial Marketing Management, 2006. 2006: p. pp. 394-402.

28. Anuntaruttana, T. and T. Roopsing, Model Development of Innovative Wood Substitutes for the Sustainable Growth of the Thai Wood Substitution Industry. Journal of Open Innovation: Technology, Market, and Complexity, 2020. 6(1): p. 17.

29. Rakthai, T., S. Aujirapongpan, and K. Suanpong, Innovative capacity and the performance of businesses incubated in university incubator units: Empirical study from universities in Thailand. Journal of Open Innovation: Technology, Market, and Complexity, 2019. 5(2): p. 33.

30. Barney, J., Firm Resources and Sustained Competitive Advantage. Journal of Management 1991. vol. 17, 1: p. pg. 99.

31. Wernerfelt, B., A resource-based view of the firm. Strategic management journal, 1984. 5(2): p. 171-180.

32. Wernerfelt, B., A Resource-based View of The Firm. Strategic Management Journal, 1984. 5: p. 171-180.

33. Barney, J., Firm Resource and Sustained Competitive Advantage. Jounal of Management, 1991. 17(1): p. 99-120.

34. Shih, T.-Y. and C.-C. Yang, Generating intangible resource and international performance: insights into enterprises organizational behavior and capability at trade shows. Journal of Business Economics and Management, 2019. 20(6): p. 1022-1044.

35. Lee, C., K. Lee, and J.M. Penning, Internal Capabilities, Eternal Networks, and Performance: A Study on Technology Based Ventures. Strategic Management Journal, 2001. Vol. 22: p. pg. 615-640. 
36. Newbert, S.L., Value, rareness, competitive advantage, and performance: a conceptual-level empirical investigation of the resourcebased view of the firm. Strategic Management Journal, 2008. 29(7): p. 745-768.

37. Singh, K., et al., A study on the determinants of financial performance of US agricultural cooperatives. Journal of Business Economics and Management, 2019. 20(4): p. 633-647.

38. Hunt, S.D. and R.M. Morgan, Resource-advantage theory: A snake swallowing its tail or a general theory of competition? Journal of Marketing, 1997. Vol. 61. no. 4: p. pg. 74.

39. Morgan, N.A., Marketing and business performance. Journal of the Academy of Marketing Science, 2011. 40(1): p. 102-119.

40. Chew, D.A.S., S. Yan, and C.Y.J. Cheah, Core capability and competitive strategy for construction SMEs in China. Chinese Management Studies, 2008. 2(3): p. 203-214.

41. Porter, M.E., Competitive Strategy. 1985, New York: The Free Press.

42. Lynn, G.S. and A.E. Akgun, Innovation strategies under uncertainty: a contingency approach for new product development. Engineering Management Journal, 1998. 10(3): p. 11-17.

43. Lynn, G.S., et al., Learning is the critical success factor in developing truly new products. Research Technology Management, 1998. 41: p. 45.

44. Asim, Z. and S. Sorooshian, Exploring the Role of Knowledge, Innovation and Technology Management (KNIT) Capabilities that Influence Research and Development. Journal of Open Innovation: Technology, Market, and Complexity, 2019. 5(2): p. 21.

45. Nitsenko, V., et al., Pricing in the Concept of Cognitive Marketing in the Context of Globalization: Theoretical, Methodological and Applied Aspects Montenegrin Journal of Economics 2019. Vol. 15(No. 4): p. p. 131-147.

46. Bertrand, O. and M.J. Mol, The antecedents and innovation effects of domestic and offshore RED outsourcing: The contingent impact of cognitive distance and absorptive capacity. Strategic Management Journal, 2013. 34(6): p. 751-760.

47. Karbowski, A., Cooperative and non-cooperative RED in product innovation and firm performance. Journal of Business Economics and Management, 2019. 20(6): p. 1121-1142.

48. Alpkan, L., et al., Organizational support for intrapreneurship and its interaction with human capital to enhance innovative performance. Management decision, 2010.

49. Mooi, E., J. Rudd, and A. de Jong, Process innovation and performance: the role of divergence. European Journal of Marketing, 2020. 54(4): p. 741-760.

50. Eshlaghy, A.T. and A. Maatofi, Learning Orientation, Innovation and Performance. European Journal of Social Sciences, 2011. Volume 19, Number 1.

51. Lin, C.-H. and C.-H. Peng, The innovativeness effect of market orientation and learning orientation on business performance. International Journal of Manpower, 2008. Vol. 29 No. 8,: p. pp. 752-772.

Prabowo, R., et al., New Product Development from Inactive Problem Perspective in Indonesian SMEs to Open Innovation. Journal of Open Innovation: Technology, Market, and Complexity, 2020. 6(1): p. 20.

53. Najib, M. and A. Kiminami, Innovation, cooperation and business performance. Journal of Agribusiness in Developing and Emerging Economies, 2011. Vol. 1 No. 1: p. pp. 75-96.

54. Eris, E.D. and O.N.T. Ozmen, The Effect of Market Orientation, Learning Orientation and Innovativeness. International Journal of Economic Sciences and Applied Research 5, 2012. vol. 05. 01: p. pp. 77-108.

55. Gomezel, A.S. and D. Aleksić, The relationships between technological turbulence, flow experience, innovation performance and small firm growth. Journal of Business Economics and Management, 2020. 21(3): p. 760-782.

56. Nuryakin, Competitive Advantage and Product Innovation Key Success of Batik SMES Marketing Performance In Indonesia. Academy of Strategic Management Journal 2018. Vol 17(2): p. p. 1 - 17.

57. Nandakumar, M.K., A. Ghobadian, and N. O'Regan, Business-level strategy and performance The moderating effects of environment and structure. Management Decision, 2010. Vol. 48 No. 6,: p. pp. 907-939.

58. Chew, D.A.S., S. Yan, and C.Y.J. Cheah, Core capability and competitive strategy for construction SMEs in China. Chinese Management Studies, 2008. Vol. 2 No. 3: p. pp. 203-214. 
59. Holtzman, Y., Innovation in research and development tool of strategic growth. Journal of Management Development, 2008. Vol. 27 No. 10: p. pp. 1037-1052.

60. Lin, C.Y.-Y. and M.Y.-C. Chen, Does innovation lead to performance An empirical study of SMEs in Taiwan. Management Research News, 2007. Vol. 30 No. 2,: p. pp. 115-132.

61. Meroño-Cerdán, A.L., P. Soto-Acosta, and C. López-Nicolás, How do Collaborative Technologies Affect Innovation in SMEs. International Journal of e-Collaboration, 2008. Volume 4,(4): p. pp. 33 - 50.

62. Taylor, A., The next generation: Technology adoption and integration through internal competition in new product development. Organization Science, 2010. 21(1): p. 23-41. 